\title{
FANUC SPIDER ROBOT PNEUMATIKUS ÉS KIMENETI RENDSZERÉNEK KIÉPÍTÉSE, VALAMINT TESZTELÉSE
}

\section{DEVELOPMENT AND TESTING OF THE PNEUMATIC AND OUTPUT SYSTEM OF THE FANUC SPIDER ROBOT}

\author{
Korsoveczki Gyula, ${ }^{1}$ Husi Géza, ${ }^{2}$ Erdei Timotei István ${ }^{3}$ \\ Debreceni Egyetem, Debrecen, Magyarország \\ ${ }^{1}$ korsoveczki.gyula@gmail.com \\ ${ }^{2}$ husigeza@eng.unideb.hu \\ ${ }^{3}$ timoteierdei@eng.unideb.hu
}

\begin{abstract}
The topic of the given project is based on the development and testing of the pneumatic and output system of the FANUC Spider selecting robot that can be found at the Mechatronics Department, Engineering Faculty of the University of Debrecen. As result the robot became capable of several working procedure with the use of the pneumatic vacuum gripper and the use of digital outputs.
\end{abstract}

Keywords: FANUC, spider robot, delta-parallel tripod, pneumatics, 3D printing.

\section{Összefoglalás}

A feladatmegvalósítás során a Debreceni Egyetem Műszaki Karán található FANUC Spider válogató robot pneumatikus és kimeneti rendszerének kiépítése valósult meg, valamint az elvégzett fejlesztések tesztelésre kerültek. Ennek eredményeként a robot képessé vált a pneumatikus vákuummegfogóval történő munkavégzésre, illetve digitális kimenetek használatára.

Kulcsszavak: FANUC, spider robot, delta-parallel tripod, pneumatika, 3D nyomtatás.

\section{Bevezető}

A Debreceni Egyetem Épületmechatronikai Kutatóközpontjában, a „Cyber-Physical and Intelligent Robot Systems Laboratory”-ban, új technológiák kerülnek kifejlesztésre az ipar számára. A Mechatronikai Tanszéken található KUKA KR5 ipari robot [1] munkakörének bővítése történt meg egy korábbi fejlesztés során, egy köré épített robotcella lévén. A „Workstation”-önök révén lehetőség nyílik a laborban lévő robotegységek egyidejü összehangolt alkalmazására, mely az Ipar 4.0-ra keresztelt negyedik ipari forradalom egyik alapvetése [2], [3], [4]. A projekt célja folytatván az előbbi irányvonalat, egy modern ipari robot funkcióinak bővítése és lehetséges munkakörének tágítása volt a pneumatikus és kimeneti rendszerének megfelelő kiépítésével.

\section{A robot és tartozékainak bemutatása}

A projekt tárgyát képező robot egy delta-parallel kialakítású, hibrid párhuzamos kinematikával rendelkező válogató tripod, amit a japán FANUC Corporation gyártott. A robot $6 \mathrm{db}$ tengellyel rendelkezik, szabadságfokainak száma pedig szintén 6db. Maximális kinyúlása 280mm, maximális sebessége pedig $4000 \mathrm{~m} / \mathrm{s}$. A robot ismétlési pontossága $+/-0.02 \mathrm{~mm}$, valamint $0.5 \mathrm{~kg}$ hasznos teher elbírására képes. Teljes mechanikai tömege 23kg, tápellátás igénye pedig $50 / 60 \mathrm{~Hz}, 200-230 \mathrm{~V}, 1$ fázis. Előszeretettel alkalmazzák a robotot az elektronikában, finommechanikában, optikai-iparban, orvosi műszerek gyártásában és a gyógyszeriparban [5].

A robot fő vezérlésé és működtetéséért a FANUC R-30iB Mate Open Air vezérlőszekrény látja el. 
Kompakt kialakítású, nem Windows operációs rendszer alapú, valamint keretrendszer nélküli egység [6].

Az iPendant Touch a FANUC saját gyártású kézi kontrollere, mely lehetőséget ad a robot irányítására és ON_LINE indirekt programozására [7]. A robot és a fő tartozékai az 1. ábrán láthatók:

\section{A kapcsolóáramkör megtervezése}

A kimenetek fizikai elhelyezkedése a robot burkolata alatt található, jelszintjük pedig 24V egyenfeszültség. Egy kisméretű fekete csatlakozó tartalmazza őket és biztosít hozzáférést a felhasználók számára.

A kapcsolóáramkör feladata, hogy a robot adott kimenetéről érkező 24V-os jelfeszültség hatására működtesse a hozzá tartozó relét, és ezzel az elektropneumatikus mágnesszelepet. Az áramkör tartalmaz 2 db integrált áramkört, melyek fejenként 16 db lábbal rendelkeznek. Az első integrált áramkör 1-es, 3-as, 5-ös és 7-es lábaira, valamint a második integrált áramkör 1-es és 3-as lábaira rendre az RO1, RO2, RO3, RO4, RO5 és RO6 robot kimenetek vannak csatlakoztatva, kimenetenként $1 \mathrm{db}$ 2,5k $\Omega$ nagyságú ellenállás sorba kapcsolásával. Az első integrált áramkör 2-es, 4-es, 6-os és 8-as, valamint a második integrált áramkör 2-es és 4-es lábai pedig a FANUC GND kimenetével vannak összekötve. Az első eszköz 16-os, 14-es, 12-es és 10-es lábaira és a második eszköz 16-os és 14-es lábaira $24 \mathrm{~V}$ tápegységi egyenfeszültség csatlakozik, míg a 15-ös 13-as, 11-es, 9-es, illetve a második integrált áramkör 15-ös és 13-as lábai pedig Darlington-ok bázis lábaira vannak kötve, Darlington-onként egy 4,7k $\Omega$ nagyságú ellenállás segítségével. Alkalmazásra került egy tápegység, mely $24 \mathrm{~V}$ egyenfeszültség és 3A egyenáram szolgáltatásra képes. A Darlington-ok kollektor lábai a tápegységi egyenfeszültséghez csatlakoznak, míg az emitter lábak a tápegység GND csatlakozására. Mivel a kimenetek, illetve a Darlington-ok nem közös földre vannak kötve, így megvalósul a galvanikus leválasztás, ami védelmet nyújt a robot számára az áramkör esetleges meghibásodásakor. A kapcsolóáramkör tartalmaz továbbá Dar-

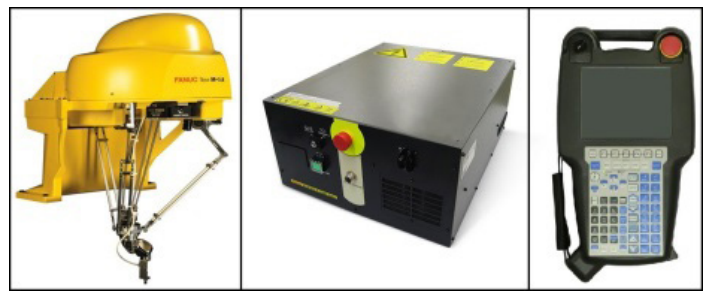

1. ábra. A robot és fö tartozékai [5] [6] [7] linton-onként 1 db védődiódát, amik a relékkel vannak párhuzamosan bekötve a 24 V-os tápegységi egyenfeszültségre és a Darlington-ok kollektor lábaira. Feladatuk a relé védelme a visszafolyó áramtól. A robot kimeneteiről érkező jelek egy RS232 csatlakozóba futnak be. A lábak 1-től 6-ig rendre össze vannak kötve a robot kimeneteivel R01-től RO6-ig, valamint a robot egyik GND kimenete is befut a csatlakozóba, a 9-es lábra. A jelek fogadására használt TIL199 integrált áramkörök bemeneti oldalát fejenként $4 \mathrm{db}$ infra LED alkotja, melyek nyitófeszültsége 1,2V. [8] Mivel a FANUC robot kimeneteinek jelszintje $24 \mathrm{~V}$ egyenfeszültség, ezért kimenetenként 2,5 k $\Omega$-os ellenállásokkal korlátozza le ezt a nyitófeszültség szintjére. Hasonló korlátozó szerepet látnak el a 4,7 k $\Omega$-os ellenállások is, mivel a TIP120G típusú Darlington-okat 4,4 mA áramerősség vezérli. Az áramkör kapcsolási rajza a 2. ábrán látható.

A robot kimenetéről érkező 24 V-os jelszint beérkezik az RS23 csatlakozóba, majd azt követően a 2,5k $\Omega$ nagyságú ellenállás lekorlátozza az infra

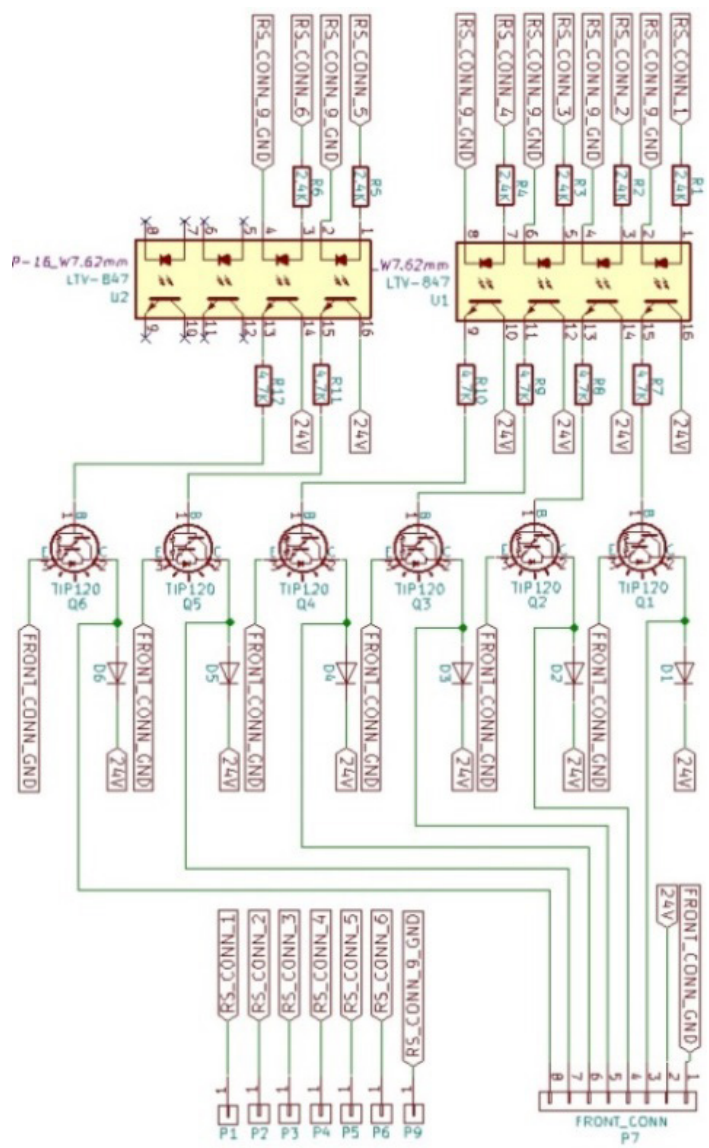

2. ábra. Az áramkör kapcsolási rajza 
LED nyitófeszültségére. Ennek hatására az infra LED kapcsolja az integrált áramkör kimeneti oldalán található foto Darlington-t, ami ebben az esetben vezető szerepet tölt be. Az átengedett áramértéket a 4,7 k $\Omega$-os ellenállás lekorlátozza a Darlington kapcsolási bázisáramának szintjére. Ennek hatására vezetőként funkcionál. Ez működésbe hozza a relét és a mágnesszelepet, ami így állást vált. A robot kimeneti jelének megszűnésével pedig a kapcsolóáramkör zár, a mágnesszelep visszatér alaphelyzetébe.

\section{Az elektropneumatikus hálózat egységei}

A működtetett egység egy pneumatikus vákuum megfogó. Teljes hossza $10 \mathrm{~mm}$, súlya pedig 5,5g. Anyaga rozsdamentes acél. Menetes csatlakoztatási lehetőséggel rendelkezik, valamint szívókorongjai cserélhetőek. Az alkalmazott szívókorong harmonika kialakítású, ezáltal érvényesül a redők rugalmas hatása így kiküszöbölhető vele kisebb felületi egyenetlenség is [9].

A vákuumképző szerv egy SMC gyártotta ZH típusú vákuum ejektor, amelynek maximális vákuum nyomása elérheti a -90 kPa nagyságot. Az egység $3 \mathrm{db}$ csatlakozással rendelkezik.[10]. Az 1 (P) csatlakozás a levegő tápellátás, a 2 (V) csatlakozása pedig a munkacsatlakozás. Az ide becsatlakozó csőszakaszban hoz létre vákuumot az ejektor. A 3 (E) csatlakozáson távozik a levegő a vákuumképzés során [10]. A sürített levegő kiáramlási zajának csökkentésére a vákuum ejektor rendelkezik egy hangtompítóval, mely az SMC által gyártott, ANA1 típusú egység, ami a hangszintet $40 \mathrm{~dB}$ alatt tartja [11].

Az alkalmazott szelep egy SMC gyártmányú, VZ51-es típusú, elővezérelt 3/2-es monostabil rugóvisszatérítéses alaphelyzetben zárt mágneszszelep. Működtetése 24V egyenfeszültséget igényel, a kapcsolt levegő nyomástartománya pedig $0,15 \mathrm{MPa}$ és $0,7 \mathrm{MPa}$ közé esik. A szelep 3 csatlakozással rendelkezik, melyek közül a 2 (A) jelü a munkacsatlakozás, az 1 (P) jelű a levegő tápellátás csatlakozása, a 3 (R) jelű pedig a leszellőzés. Állásainak száma 2. [12].

A beérkező levegő szabályozása egy SMC által gyártott, AR10-M5-Z típusú nyomásszabályozó és egy SMC G27-10-R1 típusú nyomásmérő használatával valósul meg. Helyet foglal továbbá egy indikátor is a nyomásszabályozó egységen egy 0-1MPa intervallumú skálával. Az egység hatlapfejű menetes műanyag gyürű segítségével rögzíthető átmenő furaton. [13].

Az alkalmazott egységek az 3. ábrán láthatóak:

\section{A 3D nyomtatott megfogó tartó}

A pneumatikus vákuummegfogó működtetéséhez szükség volt egy megfelelő geometriájú tartóra. Mivel a vákuum megfogó működtetéséhez a függőleges pozíció az legmegfelelőbb, így a tartó hosszmérete befolyásolja a robot felhasználható munkaterét, mivel a robot munkatere gömb alakú, ezért a magasabb Z pozíció kisebb oldalirányú mozgástartományt eredményezhet. A pneumatikus cső elvezetése szintén fontos tényező. Mivel a cső sugárpályán halad a tartóban, így annak igazodnia a kell a pneumatikus cső anyagára és a jellemző hajlítási sugárhoz, mely 20mm. A megfogó tartó a Solid Edge nevű tervezőprogram használatával és 3D nyomtatási technológiával készült.

\section{A jeltovábbítás megvalósítása}

A robotból érkező jelek megfelelő sorrendben történő gyűjtésére egy fém platform került rögzítésre annak belsejében egy RS232 csatlakozó számára. A fizikai kapcsolatot az áramkör és a platform között UTP kábel képezi. Ezt követően az áramkörhöz relék kerültek társításra, melyek általános célú Finder 55.34.9.024.0040 típusszámú kisméretű ipari relék, valamint Finder 94.74 típusú jelfogó foglalatok, amelyek kompatibilisek a 35mm-es szabvány DIN sínnel, ahogyan a kapcsolóáramkört tartalmazó doboz, illetve a tápegység is. Az elektropneumatikus működtetés, valamint kapcsolata az áramkörrel a 4. ábrán látható.

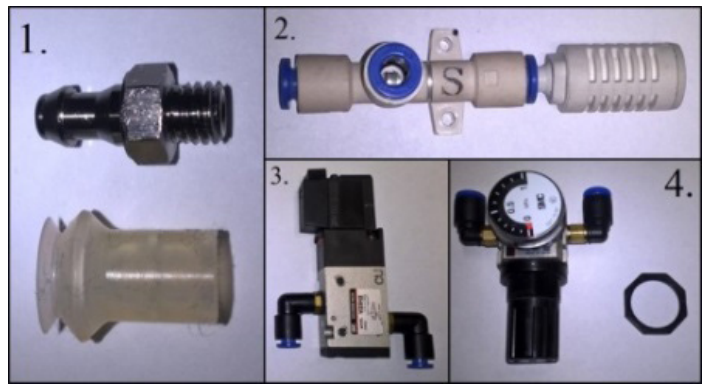

3. ábra. Az alkalmazott egységek

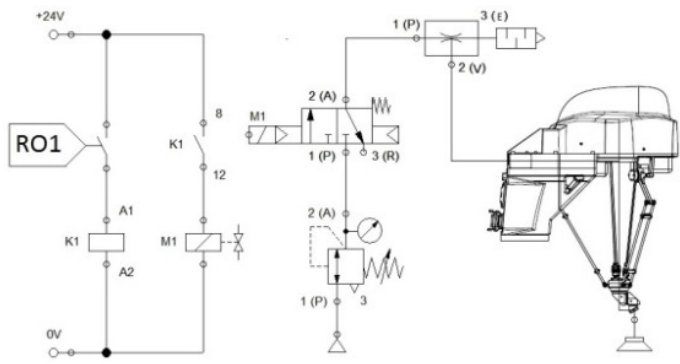

4. ábra. A müködési vázlat 


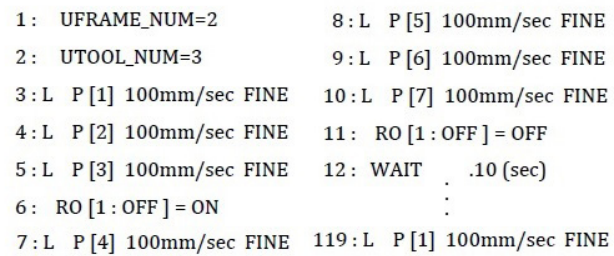

[END]

\section{5. ábra. Az áramkör kapcsolási rajza}

A kimeneti 24 V-os jelfeszültség esetén a kapcsolóáramkör működésbe hozza a megfelelő relét és jelen esetben a mágnesszelepet. A megfogó vezérlése az RO1 kimenettel és a K1-es relével történik. Amíg a robot kimenetén jelen van a 24 V-os jelszint, jelen van a vákuum. A jel megszünésével pedig az is megszünik.

A pneumatikus egységek stabil elhelyezésének céljából egy hegesztett, fém platform készült, továbbá a feladatvégzés optimalizálásához egy munkaasztal is, mely a robot WORLD koordináta rendszerének X, Y, és Z irányával párhuzamosan állítható.

\section{A tesztprogram}

Utolsó lépésként az elvégzett fejlesztések tesztelése történt meg egy tesztprogram révén. A program egy „pick and place” folyamatot valósít meg, melynek során eltérő alakú, súlyú és felületű munkadarabok mozgatása történik. A programkód részlete az 5 . ábrán látható:

\section{Következtetések}

A projekt során a robot elektropneumatikus megfogó rendszere, valamint digitális kimeneti rendszere került kiépítésre, melynek köszönhetően feladatköre és lehetőségei jelentősen bővültek. További fejlesztési lehetőség a robotcella kiépítése, mely magába foglal konvejorpályát, szenzorokat és aktuátorokat, valamint kamerarendszert.

\section{Szakirodalmi hivatkozások}

[1] Erdei T. I., Molnár Zs., Obinna N. C., Husi G.: Cyber physical systems in mechatronic research centre. MATEC Web Conference, 126. (2017). https://doi.org/10.1051/matecconf/201712601006

[2] Erdei T. I., Molnár Zs., Husi G.: Robot visual and virtual control technology in industrial environ- ment. WoS (Web of Science) publication, International Symposium on Small-Scale Intelligent Manufacturing Systems (SIMS), Narvik, NORWAY- IEEE, Jun 21-24, 2016.

https://doi.org/10.1109/SIMS.2016.7802902

[3] Erdei T. I., Molnár Zs., Obinna N. C., Husi G.: A Novel Design of an Augmented Reality Based Navigation System \& its Industrial Applications. 15th IMEKO TC10 - Technical Diagnostics in Cyber-Physical Era Budapest, Hungary, 6 - 7 June, 2017 - Organised by: MTA SZTAKI - Hungarian Academy of Sciences - Institute for Computer Science and Control.

[4] Obinna N. C., Erdei T. I., Molnár Zs., Husi G.: LabVIEW Motion Planning and Tracking of an Industrial Robotic Manipulator (KUKA KR5 arc): Design, Modelling, and Simulating the Robot's Controller Unit. In: A XXII. Fiatal műszakiak tudományos ülésszak előadásai. Proceedings of the $22^{\text {th }}$ international scientific conference of youngth engineers, Kolozsvár/Cluj, Románia, Müszaki Tudományos Közlemények 7. (2017). https://eda.eme.ro/handle/10598/29838

[5] FANUC Hungary Kft., $M-1 i A$ 0.5A.

http://www.fanuc.eu/hu/hu/robotok/robotsz\%c5\%b1r\%c5\%91-lap/m1-sorozat/m-1ia05a. [Hozzáférés dátuma: 23.02.2019.].

[6] FANUC America Corporation, R-30iA Mate controller. [Hozzáférés dátuma: 23.02.2019.]

http://www.msamc.org/aimss/documentation/pdf/manuals/lr_mate_manuals/R30iA\%20 Mate\%20Controller.pdf

[7] FANUC Hungary Kft., FANUC iPendant Touch. http://www.fanuc.eu/hu/hu/robotok/tartoz\%c3\%a9kok/r-30ib-vez\%c3\%a9rl\%c5\%91/ipendant-touch. [Hozzáférés dátuma: 23.02.2019.].

[8] Alldatasheet, TIL199. [Hozzáférés: 23.02.2019.] https://pdf1.alldatasheet.com/datasheet-pdf/ view/85195/ETC/TIL199.html

[9] Mátyás A.: Vákuum megfogó és ejektor,” Vákuumos megfogó- és emelőberendezések, 22.10.2005.

[10] SMC Pneumatics, Vacuum Equipment. https://www.smcpneumatics.com/pdfs/ZH.pdf [Hozzáférés dátuma: 23.02.2019.].

[11] SMC Pneumatics, ANA1 Silencer. https://content2.smcetech.com/pdf/ana1.pdf [Hozzáférés dátuma: 23.02.2019.].

[12] SMC Pneumatics, 3 port Solenoid Valve, https://content.smcetech.com/pdf/VZ500.pdf [Hozzáférés dátuma: 23.02.2019.].

[13] SMC Pneumatics, Pressure Gauge for General Purpose. Hozzáférés dátuma: 23.02.2019.]. https://datasheet.octopart.com/G27-10-R1-SMCdatasheet-32029199.pdf. 